\title{
TUMBUHAN AIR DI DANAU LIMBOTO, GORONTALO: MANFAAT DAN PERMASALAHANNYA
}

\author{
Astri Suryandari dan Yayuk Sugianti \\ Peneliti pada Loka Riset Pemacuan Stok Ikan, Jatiluhur-Purwakarta \\ Teregistrasi I tanggal: 24 Juni 2008; Diterima setelah perbaikan tanggal: 20 Nopember 2008; \\ Disetujui terbit tanggal: 21 Januari 2009
}

\begin{abstract}
ABSTRAK
Danau Limboto cenderung semakin hari, semakin menurun luasnya. Luas danau pada tahun 1932 mencapai 8.000 ha, pada tahun 1970 menurun menjadi 4.500 ha. Pada tahun 1993, perairan ini mengalami penurunan luasnya menjadi 3.057 ha dengan kedalaman maksimumnya 2,3 $\mathrm{m}$ dan pada tahun 2004 tersisa 3.000 ha. Masalah pendangkalan dengan laju sedimentasi $1,5 \mathrm{~cm}$ per tahun dan perkembangan populasi tumbuhan air (rumput liar dan eceng gondok, Eichhornia crassipes) yang telah mencapai luas $9.420 \mathrm{~m}^{2}$ menjadi ancaman bagi sumber daya perikanan di danau tersebut. Tujuan dari tulisan ini adalah untuk mengetahui jenis tumbuhan air serta menggambarkan kondisinya di Danau Limboto beserta manfaat dan permasalahannya. Hasil pengamatan menunjukkan bahwa di Danau Limboto ditemukan 9 jenis tumbuhan air, meliputi tipe tumbuhan yang muncul di tepian danau, yang tenggelam dan berakar di dasar, dan yang mengapung bebas ataupun yang berakar. Jenis tumbuhan yang dominan adalah eceng gondok yang telah menjadi gulma.
\end{abstract}

\section{KATA KUNCI: tumbuhan air, Danau Limboto, Gorontalo}

\section{PENDAHULUAN}

Danau Limboto terletak di Provinsi Gorontalo, berfungsi pokok sebagai muara Sungai Limboto dan 20 anak sungainya. Ada 4 sungai besar yaitu Sungai Bionga, Molalahu, Pohu, dan Meluopo yang bermuara ke dalam Danau Limboto. Danau Limboto termasuk danau yang subur dan telah mengalami eutrofikasi serta memiliki potensi produksi perikanan antara 262,7 $-589,9 \mathrm{~kg}$ per ha per tahun.

Kondisi lingkungan Danau Limboto semakin hari, cenderung semakin menurun. Permasalahan yang dihadapi di danau tersebut adalah sedimentasi yang tinggi dengan laju $1,5 \mathrm{~cm}$ per tahun dan eutrofikasi yang ditandai oleh pertumbuhan rumput liar dan eceng gondok (Eichhornia crassipes) yang telah mencapai luas $9.420 \mathrm{~m}^{2}$ (Kementerian Lingkungan Hidup, 2005). Proses pendangkalan danau yang tinggi menyebabkan peningkatan ancaman banjir bagi wilayah di sekitar Danau.

Luas danau pada tahun 1932 adalah sekitar 8.000 ha, pada tahun 1970 menurun menjadi 4.500 ha. Pada tahun 1993 luas perairan ini berkurang menjadi 3.057 ha dengan kedalaman maksimum 2,3 m, dan pada tahun 2004 luasnya tersisa 3.000 ha.

Masalah pendangkalan disertai dengan pesatnya perkembangan populasi tumbuhan air menjadi ancaman bagi sumber daya perikanan di Danau Limboto. Saat ini, populasi tumbuhan air di Danau tersebut diperkirakan menutupi sekitar $50 \%$ dari luas permukaan danau. Populasi tanaman air di Danau
Limboto mengalami perkembangan yang cukup pesat. Pada tahun 1999, sekitar $35 \%$ dari luas danau tertutupi oleh tumbuhan air (Sarnita, 2000). Keberadaan tumbuhan air bagi perikanan dapat memberikan keuntungan maupun kerugian, apabila populasinya sangat banyak, tumbuhan air bersifat merugikan. Jika tumbuhan air yang menutupi 10-20\% dari luas perairan tergolong baik bagi perikanan (Boyd, 1990).

Danau Limboto memiliki beberapa jenis tumbuhan air yang apabila tidak dikendalikan perkembangannya akan merugikan bagi perairan danau tersebut. Banyak jenis tumbuhan air yang bermanfaat bagi perikanan yaitu berperan dalam proses pemijahan ataupun penyedia pakan bagi berbagai jenis ikan. Namun demikian, ada pula beberapa jenis tumbuhan yang memiliki perkembangan sangat pesat dan seringkali menjadi masalah di badan air. Setiap jenis tumbuhan tersebut memiliki kemampuan berbeda dalam daya tumbuh, penyebaran dan adaptasinya.

Peningkatan populasi tumbuhan air di Danau Limboto didorong pula oleh adanya bibilo (rumpon) yang sengaja dibuat untuk menangkap ikan. Hasil dari bibilo ini cukup menjanjikan, sehingga upaya pelarangan bibilo untuk mengurangi populasi gulma air di Danau Limboto menjadi sulit.

Tujuan dari tulisan ini adalah untuk mengetahui jenis tumbuhan air di Danau limboto dan menggambarkan kondisinya serta manfaat dan permasalahannya. 


\section{BAHAN DAN METODE}

Penelitian dilakukan pada bulan Maret-Nopember 2007 dengan metode survei dan wawancara. Contoh diambil dari beberapa lokasi yang mewakili daerah outlet, inlet, bagian tengah, dan tepi danau. Tumbuhan air yang ditemukan diambil dicatat nama jenis, serta keterangan lainnya. Identifikasi tumbuhan air mengacu pada Leach \& Osborne (1985) dan Steenis (1975).

\section{HASIL DAN BAHASAN}

\section{Jenis-Jenis Tumbuhan Air}

Di Danau Limboto ditemukan 9 jenis tumbuhan air, meliputi tumbuhan yang muncul di tepian danau, yang tenggelam dan berakar di dasar, dan yang mengapung bebas, ataupun yang berakar. Jenis tumbuhan yang mendominansi perairan Danau
Limboto adalah eceng gondok (Eichhornia crassipes) yang telah dianggap gulma bagi Danau tersebut. Tumbuhan air di Danau Limboto tertera pada Tabel 1.

\section{Peran Tumbuhan Air}

Tumbuhan air memiliki hubungan dan perannya yang relatif penting bagi komponen biotik lainnya di ekosistem perairan seperti ikan. Keberadaan tumbuhan air ini dari segi jenis maupun kelimpahannya dapat menjadi indikator kondisi lingkungan perairan tersebut.

Tumbuhan air merupakan tempat berlindung bagi ikan-ikan dewasa maupun juvenil (Barnet \& Schneider, 1974). Tumbuhan air juga merupakan tempat yang disukai oleh ikan sebagai tempat untuk menempelkan telur-telurnya. Pengamatan yang dilakukan di Danau Limboto menunjukkan bahwa juvenil ikan payangka

Tabel 1. Jenis-jenis tumbuhan air yang ditemukan di Danau Limboto

\begin{tabular}{|c|c|c|c|c|}
\hline No. & Gambar & $\begin{array}{c}\text { Jenis } \\
\end{array}$ & Jumlah & Keterangan \\
\hline 1. & & $\begin{array}{l}\text { Eceng gondok } \\
\text { (Eichhornia crassipes) }\end{array}$ & 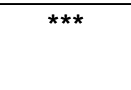 & $\begin{array}{l}\text { Mengapung bebas hampir di seluruh wilayah } \\
\text { perairan danau. }\end{array}$ \\
\hline 2. & & $\begin{array}{l}\text { Ganggang } \\
\text { (Hydrilla verticillata) }\end{array}$ & * & $\begin{array}{l}\text { Tenggelam dengan akar di dasar, ditemukan } \\
\text { di beberapa daerah dangkal. }\end{array}$ \\
\hline 3. & & $\begin{array}{l}\text { Kangkung } \\
\text { (Ipomoea aquatica) }\end{array}$ & * & Mengapung. \\
\hline 4. & & $\begin{array}{l}\text { Plambungo } \\
\text { (Ipomoea carnea) }\end{array}$ & $\star \star \star *$ & $\begin{array}{l}\text { Tumbuh di daerah tepian danau, ataupun } \\
\text { pada bibilo (rumpon). }\end{array}$ \\
\hline 5. & & $\begin{array}{l}\text { Tombili } \\
\text { (Pistia stratiotes) }\end{array}$ & * & Mengapung. \\
\hline 6. & & $\begin{array}{l}\text { Kiambang } \\
\text { (Azolla pinata) }\end{array}$ & * & Mengapung. \\
\hline 7. & & $\begin{array}{l}\text { Rumput } \\
\text { (Scirpus mucronatus) }\end{array}$ & * & Muncul di tepian. \\
\hline 8. & & $\begin{array}{l}\text { Rumput } \\
\text { (Panicum repens) }\end{array}$ & ** & $\begin{array}{l}\text { Muncul di tepian, ditemukan pula pada bibilo } \\
\text { (rumpon) bersama-sama dengan eceng } \\
\text { gondok (Eichhornia crassipes). }\end{array}$ \\
\hline 9. & & $\begin{array}{l}\text { Teratai } \\
\text { (Nelumbium sp.) }\end{array}$ & ** & Mengapung. \\
\hline
\end{tabular}

Keterangan: ${ }^{* *)}$ = banyak; ") = sedang; ") = sedikit 
(Ophiocara porocephala) ditemukan di bawah eceng gondok. Hal ini, diperkuat oleh hasil tangkapan alat tangkap dudayahu (push net) yang beroperasi di perairan yang banyak terdapat kumpulan tumbuhan air. Hasil tangkapan dudayahu ini didominansi oleh ikan-ikan muda/juvenil.

Tumbuhan air juga merupakan sumber daya pakan terutama bagi ikan-ikan herbivora. Ikan grass carp (Ctenopharyngodon idella) merupakan salah satu ikan herbivora yang memakan tumbuhan air tersebut (Cudmore \& Mandrak, 2004). Selain grass carp, tawes (Barbonimus gonionotus), dan nilem (Osteochillus hasselti) juga merupakan contoh ikan-ikan pemakan tumbuhan air (Yang, 1988). Beberapa jenis ikan yang terdapat di Danau Limboto yang memanfaatkan tumbuhan air sebagai sumber daya pakan antara lain adalah tawes, nila (Oreochromis niloticus), dan mujair (O. mossambicus).

\section{PERMASALAHAN TUMBUHAN AIR DI DANAU LIMBOTO}

Perkembangan populasi tumbuhan air yang tidak terkendali di suatu badan air akan menimbulkan masalah bagi badan air tersebut. Tumbuhan air yang berkembang semakin banyak sehingga keberadaan menimbulkan masalah disebut sebagai gulma. Populasi gulma air yang terlalu banyak akan mendatangkan kerugian bagi pemanfaatan sumber daya air. Beberapa kerugian yang ditimbulkan oleh gulma air sebagai berikut:

1. Populasi yang berlebihan akan menyebabkan pengurangan daya tampung air di Danau serta menyebabkan kehilangan air, karena proses evapotranspirasi yang berlebihan. Sebagai contoh, eceng gondok menyebabkan kehilangan air 25,3 $\mathrm{mm}$ per hari dan kiambang $6,1 \mathrm{~mm}$ per hari (Anonimus, 1982).

2. Gulma terapung akan menghambat penetrasi cahaya matahari, sehingga akan mengurangi kadar $\mathrm{O}_{2}$ terlarut dan mengganggu kedalaman air yang pada akhirnya dapat mengganggu proses produksi ikan.

3. Gulma air akan mengganggu aktivitas penangkapan ikan. Pada beberapa danau yang merupakan sumber mata pencarian bagi sebagian masyarakat seperti penangkapan ikan, semakin meningkat populasi gulma air, maka akan semakin meningkat gangguan terhadap aktivitas pekerjaan mereka. Hal ini terjadi di Danau Limboto, beberapa nelayan mengalami kesulitan saat mengoperasikan alat tangkap karena terhalang oleh populasi gulma air.
4. Gulma air akan mengganggu lalu lintas air, transportasi perahu terhambat pergerakannya karena populasi gulma air yang meningkat.

\section{PENGENDALIAN GULMA AIR}

Pengendalian gulma air dapat dilakukan dengan beberapa cara dengan mempertimbangkan berbagai aspek sampingnya, yaitu:

\section{Pengendalian secara fisik dan mekanik.}

Pengendalian dengan cara ini meliputi memotong, menyiangi, mengumpulkan, menggali, atau memetik tumbuhan air. Pemetikan atau pemotongan diulangi setiap beberapa waktu untuk mengurangi munculnya tumbuhan baru. Banyak sub marga dari vegetasi tumbuhan air dapat bereproduksi melalui fragmentasi. Kegiatan pemotongan tumbuhan dapat mengurangi rata-rata pertumbuhan dan banyak nutrien yang dibutuhkan (Angelo \& Hock, 1998).

\section{Pengendalian secara kimia.}

Pengendalian secara kimia adalah dengan menggunakan bahan-bahan kimia seperti herbisida. Teknik pengendalian dengan cara ini harus hati-hati. Pengendalian dengan teknik ini hanya dimungkinkan untuk kolam buatan yang dimiliki oleh pribadi. Cara tersebut tidak direkomendasikan untuk pengendalian pada badan air yang luas, karena akan berbahaya bagi organisme lain seperti ikan ataupun manusia.

\section{Pengendalian secara biologi.}

Teknik pengendalian dengan cara ini sudah banyak dipergunakan baik di dalam maupun di luar negeri. Teknik ini menggunakan organisme pemakan gulma. Ikan pemakan tumbuhan seperti koan atau grass carp dan tawes. Salah satu pengendalian gulma air eceng gondok di Indonesia dengan menggunakan ikan grass carp (Ctenopharyngodon idella) telah berhasil dilakukan di Danau Kerinci Jambi (Hartoto et al., 2000).

Sampai saat ini, upaya pengendalian gulma air di Danau Limboto sudah beberapa kali dilakukan oleh Pemerintah Daerah setempat dengan cara pemanenan untuk dimanfaatkan sebagai kompos. Namun, hal itu belum mengurangi jumlah gulma yang menutupi perairan danau. Untuk itu, diperlukan upaya lain seperti menebar ikan yang dapat memanfaatkan tumbuhan air sebagai pakan seperti ikan koan. 


\section{PEMANFAATAN GULMA AIR}

Pengendalian gulma air juga dapat dilakukan dengan cara memanfaatkannya untuk kepentingan tertentu. Beberapa cara yang dapat dilakukan adalah sebagai berikut:

\section{Kompos}

Gulma air dapat dimanfaatkan sebagai kompos. Jenis gulma yang digunakan sebagai kompos adalah eceng gondok dan kiyambang (Savinia spp.). Kompos eceng gondok dapat menyuburkan tanah karena menambah unsur hara dan juga memperbaiki keadaan fisik tanah. Kandungan mineral eceng gondok yang telah dijadikan kompos adalah $0,9-25 \% \mathrm{~N}, 0,15 \% \mathrm{P}$ dan $0,16 \%$ K. Petani di daerah Garut sudah terbiasa memanfaatkan kiyambang sebagai kompos (Anonimus, 1982).

\section{Sumber Energi}

Krisis energi yang timbul sejak awal tahun 1970 sampai sekarang belum teratasi secara baik. Harga sumber energi menjadi meningkat di pasaran. Keadaan ini memerlukan pemikiran untuk mengatasi krisis energi tersebut. Salah satu cara untuk mengatasi kekurangan energi adalah dengan memanfaatkan bahan-bahan organik. Hasil sampingan dari pengolahan bahan organik adalah gas yang dapat digunakan sebagai sumber panas untuk lampu atau penerangan ataupun memasak. Tumbuhan air jenis eceng gondok dapat digunakan untuk menghasilkan bio gas tersebut (Anonimus, 1982). Melalui proses tertentu eceng gondok dapat menghasilkan bio gas. Dalam hal ini yang dihasilkan adalah gas metan $\left(\mathrm{CH}_{4}\right)$.

\section{KESIMPULAN}

Di Danau Limboto ditemukan 9 jenis tumbuhan air, dan jenis yang paling banyak ditemukan adalah eceng gondok (Eichhornia crassipes). Adanya penutupan oleh eceng gondok dapat menimbulkan efek negatif bagi perairan Danau Limboto. Untuk itu, diperlukan upaya pengendalian dengan memperhatikan berbagai aspek, sehingga upaya tersebut dapat berhasil seperti yang diinginkan.

\section{PERSANTUNAN}

Kegiatan dari hasil riset konservasi dan rehabilitasi sumber daya perikanan di Danau Limboto, Gorontalo, T. A. 2008, di Loka Riset Pemacuan Stok Ikan, Jatiluhur-Purwakarta.

\section{DAFTAR PUSTAKA}

Angelo, D. J. \& W. K. Hock. 1998. Pond Management and Aquatic Plant Control. The Pennsylvania State University. 1998.

Anonimus. 1982. Pemanfaat Gulma Air. Departemen Pertanian, Jakarta.

Anonimus. 2005. Data Base Danau Indonesia. Asdep Urusan Pengendalian Kerusakkan Sungai dan Danau. Deputi Bidang Peningkatan Konservasi Sumber Daya Alam dan Pengendalian Kerusakkan Lingkungan. Kementerian Lingkungan Hidup. Jakarta.

Barnet S.B. \& Robert W. Schneider. 1994. Fish Population in Dense Submersed Plant Communities. Hyucinth Control Journal. 12-14.

Boyd, C. E. 1990. Water Quality in Ponds for Aquaculture. Alabama Agricultural Experimental Station. Auburn University. Alabama.

Cudmore, B. \& N. E. Mandrak. 2004. Biological synopsis of gras carp (Ctenopharyngodon idella). Canadian Manuscript Report of Fisheries and Aquatic Sciences 2705. Fisheries and Oceans Canada Great Lakes Laboratory for Fisheries and Aquatic Sciences. Canada.

Hartoto, D. I., Sumantadinata, Awalina, \& Yustiawati. 2000. Water hyacinth control using grass carp (Ctenopharyngodon idella) and its related limnological changes In Lake Kerinci, Indonesia. Dipresentasikan pada Semi Loka Nasional Pengelolaan dan Pemanfaatan Danau dan Waduk. Fakultas Perikanan. Universitas Padjadjaran. 7 Nopember 2000.

Leach G. J \& Partick C. Osborne. 1985. Freshwater Plant of Papua New Guinea. The University of Papua New Guinea Press.

Sarnita, A. 1994. Kajian tentang sumber daya perikanan di Danau Limboto, Sulawesi Utara. Prosiding Seminar Perikanan Air Tawar. Balai Penelitian Perikanan Air Tawar.

Yang, S. Y. 1988. Food resource utilization partitioning of fifteen fish species at Bukit Merah Reservoir, Malaysia. Hydrobiologia. 157: 143-160. 